\title{
IMPACTS OF EDUCATIONAL FACTORS ON ECONOMIC GROWTH IN REGIONS OF CHINA: A SPATIAL ECONOMETRIC APPROACH
}

\author{
Kangjuan LV, Anyu YU, Siyi GONG, Maoguo WU, Xiaohong XU \\ SILC Business School, Shanghai University, 20 Chengzhong RD. Jiading District, \\ 201800 Shanghai, P.R. China
}

Received 02 October 2012; accepted 11 January 2015

\begin{abstract}
This paper investigates the impacts of educational factors on economic growth across 31 provinces during 1996 and 2010 in China. A spatial panel estimation model is applied to study the impacts of education on economic growth taking into account the spatial spillover effects in Feder model and the cumulative effect. The results reveal that (1) educational factors are significantly spatially autocorrelated. Educational factors have spatial spillover effects. Regional differences of education impacts still exist. (2) Average schooling year has a more positive effect on economic output than capital investment and labor force. Basic education might play a more important role in economic growth. (3) Education sector also benefits non-education sectors on economic growth if "spatial effects of economic shocks" are considered. Some policies that may enhance education development and their impacts on economic growth are proposed.
\end{abstract}

Keywords: spatial panel model, economic growth, Feder model, educational factor, cumulative effect, spillover effect.

JEL Classification: I25, R12.

\section{Introduction}

Since Chinese government introduced economic reforms and opening policies in 1978, sharp increase has occurred in regional Gross Domestic Product (GDP). In contrast to the average annual GDP growth rate of 5.3\% during 1960 and 1978, the annual growth rate in 2012 reached $10.57 \%$. Moreover, national GDP rose from 364.5 billion RMB in 1978 to 40.15 trillion RMB (all figures at current market prices) in 2010. A similar result applies if GDP is measured in Purchasing Power Parity. This remarkable economic growth leads China to become the second largest economy in the world in 2010.

This article has been corrected since first published. Please see the statement of correct (DOI http://dx.doi.org/10.3846/20294913.2015.1109290 of the corrigendum).

Corresponding author Kangjuan Lv

E-mail:lvkangjuan@shu.edu.cn 
To realize this rapid economic growth, more skillful and educated labors are required urgently, which leads education development to keep a similar pace with national economic growth. Due to the fact that public education in China was quite poor before the economic reforms in 1978 (only $40.9 \%$ of junior middle school graduates could enter senior middle schools), several policies have been made to improve public education across the whole nation. Firstly, the annual "national college entrance examination" resumed in 1978, enabling more efficient allocation of education resources to colleges. The compulsory education law was passed in 1986, imposing "nine-year compulsory education" on all Chinese children. Furthermore, Chinese government proposed a strategy of "prosper the nation by science and education" in 1995, which attached national importance to education and science. Thirdly, "Project 211" and "Project 985" (in 1995 and 1998, respectively) aim to construct a series of high quality universities in 21st century. Moreover, at the beginning of the ninth five-year plan, the evolution of China's education system started. Non-public capital investment was allowed to be made in the education sector. Government expenditure on education has been rapidly increasing, especially expend the expenditure of higher education (Li et al. 2014). China has basically eliminated illiteracy among young and middleaged people. In the tenth five-year plan, government expenditure on education further increased. Vocational education expenditure was strongly advocated. More scholarships and education subsidies were established. Implements of compulsory education in poor regions in the northwest and ethnic minority regions was stressed. During the eleventh five-year plan, tuition fees for nine-year compulsory education were exempt (Zhang 2014), and government expenditure on education was aimed to account for a higher percentage (4\%) of GDP. The reduction in urban-rural education disparity was also considered when making national policies. Furthermore, the twelfth five-year plan in 2011 announced that investment in special education schools, development in information technology, and international cooperation should be advocated in China's education.

For further improvement and adjustment, impacts of education policies should be further investigated, especially the impacts on national economic output. Recent education developments in China should be investigated in detail. Based on previous research results, education expenditure and average schooling years are regarded as the factors that measure the inputs of education quantity and education quality (Lin 2003; Ganegodage, Rambaldi 2011). To depict the education developments in China, changes of both factors during 1996 and 2010 are described in Figure 1. Figure 1 indicates that the ratio of education expenditure to total GDP remained stable $(3.07 \%$ - 3.90\%) during China's three five-year plans
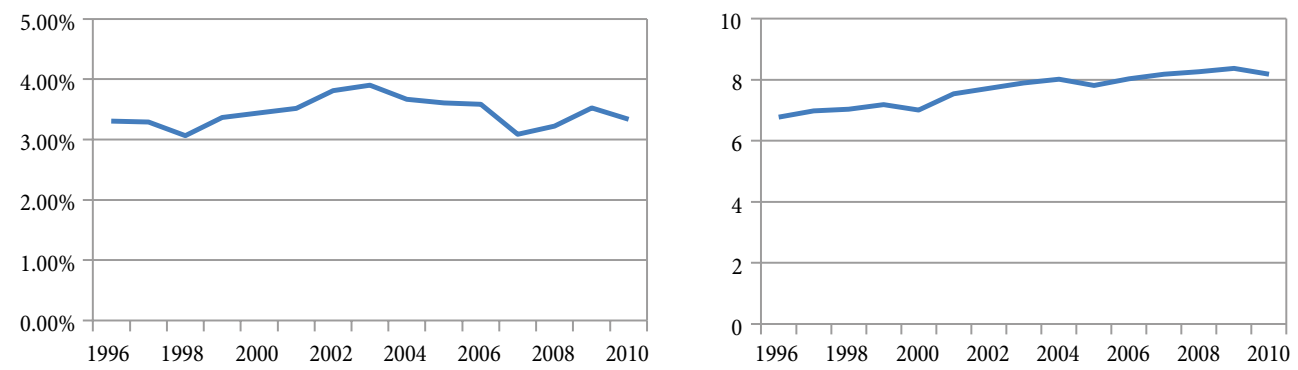

Fig. 1. Ratio of education expenditure to GDP and average schooling years during 1996 and 2010 
(1996-2000, 2001-2005 and 2006-2010, respectively). The increase of education expenditure kept a similar pace with the sharp economic growth during 1996 and 2010. Meanwhile, a stable growth in national average schooling years was also maintained. Abovementioned results indicate that education development is closely associated with economic growth. It can be explained by the fact that the development of education contributes to higher wages and lower unemployment rates, which might lead to more innovation potentials to upgrade technology. This fact might result in regional economic growth.

In order to measure the effects of educational factors on economic growth in China, two issues should be further analyzed. (1) How to analyze the impacts of educational factors and their spatial distribution on economic growth across Chinese provinces. (2) How education expenditure affects non-education sector on increasing regional economic growth.

Regarding the first issue, the fact that education interactions among different regions affect economic growth should be considered. Given the vast territory of China, there are significant disparities in regional education developments and unbalanced distribution of education inputs. Thus, it is assumed that spatial spillovers in educational factors as well as economic output affected by impacts of educational factors occur among Chinese provinces. This assumption is to be further investigated. The spatial effect of education can be defined in three aspects. The first is that knowledge capital (e.g., educated labor force and academic achievements) might move across neighboring regions. The movement is caused by pursuit of jobs or business activities. The second can be caused by local educational patterns, which may affect surrounding regions (e.g., schools or educational institutions located in different regions and students who exchange across adjacent regions) (Blair, Staley 1995). The third is about social activities, i.e., people may live in one region but study in other regions. This causes people to migrate across neighboring regions. Thus, we argue that the spatial effects in education cross regions should be considered. About the second issue, it can be assumed that education expenditure does not only increase national economic output directly, but also increases the economic output of non-education sectors indirectly. This indirect impact can be regarded as the spillover effect of education sector, i.e., education sector can provide human capital (e.g., educated labor force) for production in non-education sectors (Cai 1999).

To further analyze the economic impacts of different educational modes, education is classified into university education and basic education. Due to lack of data, vocational education and special school education are not included in the estimation. In contrast to university education, education in primary school and middle school is basic and less professional. Therefore, basic education in this paper is defined as the sum of primary school, junior middle school, and senior middle school. Given the main purpose of university education is to fit students for their career while the purpose of basic education is not, the economic impacts of university education and the economic impacts of basic education are investigated separately.

It is assumed that there is spatial spillover from educational factors to economic growth across provinces in China. The spatial methodology is explored to estimate the impacts of educational factors on economic growth across 31 Chinese provinces during 1996 and 2010 (from the ninth five-year plan to the eleventh five-year plan). Furthermore, direct impacts and spillover effects of educational factors are calculated in spatial panel models. Differences and spillover effects between education and non-education sectors are also measured. 
Main contributions of the paper are described below (all data are between 1996 and 2010 across 31 Chinese provinces). (1) To our best knowledge this is the first application of the spatial panel model to estimate the impacts and spillover effects of regional education factors on economic growth in different regions of China. The impacts of basic education and university education in regions of China are also further examined. (2) Spillover effects from education sector on non-education sectors in terms of economic growth in Feder model are explored in spatial panel models.

The remaining part of this paper is organized as follows. Section 1 gives an overview of related literature. Section 2 describes the data and the spatial model. Section 3 discusses the empirical analysis and results. Section 4 is dedicated to policy propositions. The last section concludes the paper.

\section{Related literature}

\subsection{Impacts of education on economic growth}

Previous research indicates that the quality of labor force is an important factor in accelerating economic growth (Lucas 1988; Romer 1990). As the quality of labor force is mainly measured by the level of education, it can be inferred that there is a positive relation between economic growth and education. Similar results are found in Cai (1999), Lin (2003), Grundey and Sarvutyte (2007), and Castelló-Climent and Hidalgo-Cabrillana (2012). Cai (1999) uses the data from 194 countries (territories) to examine the contribution of education to economic growth between 1965 and 1990. It finds that education expenditure has a great contribution to economic growth. Its spillover effects are positive and remarkable. Lin (2003) examines the positive effect of education on economic growth in Taiwan during 1965 and 2000 with average schooling years as the main explanatory variable. Moreover, Castelló-Climent and Hidalgo-Cabrillana (2012) conduct an estimation of production function using cross-country data and point out that both the quality and the quantity of education have positive effects on economic growth in the long run. However, a number of papers argue that economic growth in developing countries is mainly driven by capital investment, while the human capital effect brought by education is relatively weak. Ganegodage and Rambaldi (2011) demonstrate that capital investment is the key driver of long-run economic growth. Chen and Fleisher (1996), Wei et al. (2001), Arayama and Miyoshi (2004) also provide empirical evidences from China to support this viewpoint.

\subsection{Indicators of education}

To our best knowledge, general educational factors of economic growth are education expenditure, education investment (Ganegodage, Rambaldi 2011; Pan 2014), average schooling years, internationally comparable test scores (Hanushek, Kimko 2000) and school enrollment rates (Barro 1991). Data of education investment, internationally comparable test scores and school enrollment rates are incomplete and scarce in Chinese national statistics, while average schooling years can partially reflect school enrollment rates and the workload 
of teaching staff. Thus, we choose average schooling years (labor force with specific schooling years) and education expenditure as the main explanatory variables to analyze Chinese education. Given that data of average schooling years is not available in China, we estimate average school years using the method proposed in Lin (2003).

Due to the fact that education is associated with human capital, schooling years has always been regarded as an important factor in education. As endogenous growth theory indicates that human capital leads to greater innovation and economic growth, and regional schooling years is a main factor in regional education inputs (e.g., education equipment, amount of teachers and their skills). We assume that there exists a positive relation between average schooling years and economic growth. A partial selection of literature, such as Easterly and Levine (1997), Krueger and Lindahl (2001), Castelló and Doménech (2002), Hanushek and Woessmann (2008), Jalil and Idrees (2013) provide support for this assumption.

Furthermore, education expenditure has also been recognized as an important factor in economic growth in previous studies. Shindo (2010) points out that long-run economic growth can be accelerated by education subsidies for its effects on human capital accumulation. Sala-I-Martin et al. (2004) also consider education expenditure as a main source of economic growth. In addition, the economic impact of education expenditure (both the central government's and the local governments' education expenditure) is studied by Brehm (2013). Lin (2003) and Cai (1999) consider education expenditure as an important factor in education and analyze the impacts of education expenditure on economic growth.

\subsection{Evaluation of educational impacts on economic growth}

A number of research pertains to the effect of education expenditure on economic growth (Lin 2003; Cai 1999). Various econometric approaches have also been applied for more accurate estimation of the impacts. Linear regression is a common method, e.g., Sylwester (2000) and Lin (2003). Moreover, Shindo (2010) proposes a simulation of regional economic growth from education expenditure. Frini and Muller (2012) use a multivariate cointegration method to explore the long-term relation between education and economic growth. However, very few previous studies have examined the spatial interactions of education factors or their spillovers to neighboring regions in terms of economic growth. This may result in estimation bias (LeSage, Pace 2009). Thus, along with regional specific factors, the spatial interactions between regions and the spillover effects across regions cannot be neglected.

In general, spatial panel estimation is more accurate than classical regression estimation given that neighboring regions influence each other more than distant regions do (i.e., spatial effects exist) (LeSage, Pace 2009). Therefore, spatial effects should be considered in analyzing the relation between education and economic growth. However, analysis of the spatial effect of education is quite rare. One exception is that Ghosh (2010) uses a spatial econometric framework and finds that expenditure decisions of neighboring regions have a positive effect on regions with public schools.

A number of papers (Romer 1990; Cai 1999; Lee, Malin 2013) use Cobb-Douglas production function or Feder model (the dual-sector model) to estimate the impacts of edu- 
cation on economic growth. For instance, Cai (1999) modifies Feder models to measure the impacts of education sector and the impacts of non-education sectors on economic growth. However, these papers do not consider the spatial effect of regional economic output. Hence, this paper builds up a more accurate spatial panel estimation based on Cobb-Douglas production function and Feder model.

In summary, based on previous literature, this paper estimates the impacts of educational factors on economic growth in China with Cobb-Douglas production function and Feder model by using spatial panel approach.

\section{The model and the data}

\subsection{The model}

In this section, we describe the spatial panel models: spatial autoregressive model (SAR), spatial error model (SEM) and cumulative effect analysis of spatial estimation.

\subsection{Spatial Autoregressive Model (SAR) and Spatial Error Model (SEM)}

The spatial autoregressive model mainly discusses whether the dependent variable has the diffusion phenomena in a region. As a starting point, consider the estimation of a simple spatial autoregressive model, which ideally, would be of the following form:

$$
Y=\rho W y+X \beta+\mu+\eta+\varepsilon,
$$

where $Y$ is the dependent variable (denotes economic output), which is of $n \times 1$ dimension, $X$ is the exogenous explanatory variable of $n \times k$ matrix, $\rho$ is the spatial autocorrelation coefficient, which shows the effects of neighboring regions' spillovers to the region per se, $W$ is a spatial weighted matrix of $n \times n$ order, usually a contiguity matrix, $\mu$ is an $n T \times 1$ vector of individual effect, $\eta$ is an $n T \times 1$ vector of time effect, and $\varepsilon$ is a random error term, which is of $n \times 1$ dimension. The parameter $\beta$ reflects the effect of independent variable $X$ on the dependent variable $Y$.

The spatial error model can be modeled as:

$$
\begin{aligned}
& Y=X \beta+\varepsilon ; \\
& \varepsilon=\lambda W \varepsilon+\mu+\eta+v,
\end{aligned}
$$

where $v$ is the random error vector of normal distribution, which is of $n \times 1$ dimension. $\lambda$ is the spatial autoregressive coefficient of regression residuals, which measures the effect of dependent variable's shock spilled from neighboring regions to the region per se. Other variables and parameters are the same as they are in the SAR model.

Since spatial effect items are included in spatial panel models, classical economic model is augmented with spatial effects of the dependent variable to obtain more accurate estimations. Furthermore, the coefficients of spatial panel model are usually measured by the maximum likelihood estimation (MLEs) (Elhorst 2003; LeSage, Pace 2009). This paper uses the estimation method in Lee and $\mathrm{Yu}$ (2010) to estimate the fixed effect of SAR panel model so as to avoid inconsistent estimation of variance parameter given that the timespan is short. 


\subsection{SAR and SEM Models based on Feder Model}

There is difference between the marginal factor productivity of education and non-education sector in Feder model. This paper follows the example of Cai (1999) and modifies the Feder model to estimate the effects of both sectors. The production functions of two sectors can be modeled as:

$$
\begin{gathered}
N=F\left(K_{n}, L_{n}, E\right) ; \\
E=G\left(K_{e}, L_{e}\right),
\end{gathered}
$$

where $N$ and $E$ are inputs of non-education and education sectors, respectively. $K$ and $L$ are capital investment and labor force. $n$ is non-education sector and $e$ is education sector. Judging from (4), education input depends on education expenditure and educated labor force. However, from (3), non-education productivity depends on both sectors. $K, L$ and $Y$ are modeled as:

$$
\begin{gathered}
K=K_{n}+K_{e} \\
L=L_{n}+L_{e} \\
Y=E+N
\end{gathered}
$$

where $Y$ is economic output. According to Feder model, the impacts of labor force and capital investment on economic growth are modeled as:

$$
G_{k} / F_{k}=G_{l} / F_{l}=1+\delta \text {, }
$$

where $G_{k}, F_{k}, G_{l}, F_{l}$ are the impacts of capital investment and labor force on economic growth in these two sectors. $\delta$ is the difference between impacts on economic growth in two sectors. Theoretically, $\delta$ can be 0 , larger than 0 , or smaller than 0 . If $\delta=0$, the impacts on economic growth in these two sectors are equal. If $\delta<0$, the impacts on economic growth is weaker than that of non-productivity. The opposite result applies if $\delta>0$. Substituting equations (3), (4), (5), (6), and (8) into (7) gives (Cai 1999):

$$
Y_{g}=\beta_{1} \frac{K}{Y}+\beta_{2} L_{g}+\gamma\left(\frac{E}{Y}\right) \cdot E_{g},
$$

where $\beta_{1}$ is the impact of capital on economic growth in non-education sectors, $\beta_{2}$ is the impact of labor force on economic growth in non-education sector, $\gamma$ is the total contribution of education to economic growth, including the effects of educational factors and the difference between impacts of education sector and non-educational sectors, $Y_{g}, L_{g}$ and $E_{g}$ are the growth rate of GDP, labor force and education expenditure, respectively. $K / Y$ is the ratio of capital investment to GDP, and $E / Y$ is the ratio of education expenditure to GDP. Equation (10) can be derived based on Feder model with the assumption that the impact on economic growth in non-education sector is constant.

$$
N=g\left(L_{n}, K_{n}, E\right)=E^{\theta}\left(L_{n}, K_{n}\right),
$$

where $\theta$ is the impact of education input. Furthermore, equation (11) is:

$$
\frac{\partial N}{\partial E}=\theta\left(\frac{N}{E}\right) \text {. }
$$


Based on equations (10) and (11), equation (9) can be transformed into equation (12),

$$
Y_{g}=\beta_{1} \frac{K}{Y}+\beta_{2} L_{g}+\left[\frac{\delta}{1+\delta}-\theta\left(\frac{N}{E}\right)\right] \cdot E_{g} \cdot\left(\frac{E}{N}\right) .
$$

Equation (12) is modified into:

$$
Y_{g}=\beta_{1} \frac{K}{Y}+\beta_{2} L_{g}+\left(\frac{\delta}{1+\delta}-\theta\right) \cdot E_{g} \cdot\left(\frac{E}{Y}\right)+\theta E_{g} .
$$

Modify (13) based on (1) and (2), the spatial SAR Feder model is written as

$$
Y_{g}=\rho W Y_{g}+\beta_{1} \frac{K}{Y}+\beta_{2} L_{g}+\left(\frac{\delta}{1+\delta}-\theta\right) \cdot E_{g} \cdot\left(\frac{E}{Y}\right)+\theta E_{g}+\mu+\eta+\varepsilon .
$$

The spatial SEM Feder model is:

$$
\begin{gathered}
Y_{g}=\beta_{1} \frac{K}{Y}+\beta_{2} L_{g}+\left(\frac{\delta}{1+\delta}-\theta\right) \cdot E_{g} \cdot\left(\frac{E}{Y}\right)+\theta E_{g}+\varepsilon ; \\
\varepsilon=\lambda W \varepsilon+\mu+\eta+v .
\end{gathered}
$$

\subsection{SAR and SEM Models Based on Cobb-Douglas production function}

This paper modifies the Cobb-Douglas production model with spatial matrix to describe the impacts of educational factors in a more comprehensive way. Economic output is modeled as a function of labor force, capital investment and the measures of educational input using a multiplicative Cobb-Douglas production function. The production function is written as:

$$
Y=A^{\alpha_{1}} K^{\alpha_{2}} L^{\alpha_{3}} \varepsilon,
$$

where $Y$ is economic output, $K$ is capital investment, $L$ is labor force, $\varepsilon$ is a random error term, and $A$ is an exogenous factor of knowledge and technology (denotes educational factors), $\alpha_{1}, \alpha_{2}$ and $\alpha_{3}$ are the coefficients of educational factor, capital investment and labor force, respectively. This paper follows Lin (2003) and takes natural logarithms of each variable in equation (17). The production function is transformed into:

$$
\operatorname{Ln} Y=\alpha_{1} \operatorname{Ln} A+\alpha_{2} \ln K+\alpha_{3} \ln L+\varepsilon,
$$

Augment equation (18) with educational factors and modify it into spatial model. The SAR model is therefore of the following form:

$$
L n Y=\rho W \operatorname{Ln} Y+\alpha_{1} \ln K+\alpha_{2} \ln E_{u}+\alpha_{3} \ln E_{b}+\alpha_{4} \ln L_{u}+\alpha_{5} \ln L_{b}+\alpha_{6} \ln S+\mu+\eta+\varepsilon,
$$

where $E_{u}$ is the expenditure on university education, $E_{b}$ is the expenditure on basic education, $L_{u}$ is the number of people with university education, and $L_{b}$ is the number of people with basic education. Note that the number of people is also divided by education level in this model. $S$ is the average schooling years. Similarly, the SEM model is:

$$
\begin{aligned}
& L n Y=\alpha_{1} \ln K+\alpha_{2} \ln E_{u}+\alpha_{3} \ln E_{b}+\alpha_{4} \ln L_{u}+\alpha_{5} \ln L_{b}+\alpha_{6} \ln S+\varepsilon ; \\
& \varepsilon=\lambda W \varepsilon+\mu+\eta+\nu .
\end{aligned}
$$




\subsection{Cumulative effect analysis}

Cumulative effect analysis is adopted to analyze the spatial spillover effect of educational factors on economic growth. The analysis includes estimations of direct, indirect and total impacts of explanatory variables. A previous study can be found in LeSage and Pace (2009). Model (1) can be rearranged into:

$$
Y=\left[\left(I_{N}-\lambda W\right)\right]^{-1}(X \cdot \beta+\mu+\eta+\varepsilon) .
$$

Direct effect and total effect can therefore be modeled as:

$$
\begin{gathered}
\frac{\partial y_{i}}{\partial x_{j k}}=\left[\left(I_{N}-\lambda W\right)\right]_{j, j}^{-1} \cdot \beta_{k} ; \\
\frac{\partial y_{i}}{\partial x_{k}}=\left[\left(I_{N}-\lambda W\right)\right]^{-1} \cdot e_{N} \beta_{k} .
\end{gathered}
$$

Indirect effect, then, is equal to the difference between total effect and direct effect. $I_{N}$ is an identity matrix of $n \times n, e_{N}$ is a matrix of $n \times 1$ with all the elements of $e_{N}$ being one. Other indices of these models are similar to that of equation (1). Direct and total effects of educational factors are calculated following equation (23) and equation (24), in which $\left[\left(I_{n}-\rho W\right)\right]^{-1}{ }_{j, j}$ is the $j, j$-element of the inverse matrix. The indirect effect can be calculated as the difference between the total effect and the direct effect. Here indirect effect can be interpreted as the spillover effect of variables, and total effect is the sum of direct effect and indirect effect.

\subsection{The data}

This paper uses a panel data of 31 provinces in China spanning from 1996 to 2010. It covers the three recent five-year plans of China. Data are gathered mainly from China Statistics Yearbook, China Population Statistics Yearbook, China Labor Statistics Yearbook, and 31 provincial Statistical year books, China Education Statistics Yearbook.

Table 1 provides insight into the data. Economic output $(Y)$ is the value of Gross Domestic Product (GDP). Capital investment $(K)$ denotes the growth amount of capital investment (e.g., buildings, equipment, and other inventories). Labor force $(L)$ is measured by the number of people employed. According to the definition of employment in China Statistics Yearbook, employed people represent all people aged 16 or above who are employed for payment. The unit is reported in 10 thousand people. Average schooling years $(S)$ is the total schooling years divided by total population (education affects the total population). Education expenditure $(E)$ is the total expenditure on education. This expenditure includes three main resources of education expenditure: the budget education expenditure of local government, financial allocation to provincial governments from the central government, and funds from other resources, such as education funds of enterprises and private schools.

Besides, to further analyze the impacts of educational factors, education is also divided into basic education and university education. Education expenditure includes expenditures of central government and local government. On the other hand, education expenditure and labor force are also divided into ones with basic education and with university education, which are denoted by $E_{b}, E_{u}, L_{b}, L_{u}$. All expenditures are estimated at 1996 price level. 
Table 1. Description of variables

\begin{tabular}{lllc}
\hline \multicolumn{1}{c}{ Variable } & \multicolumn{1}{c}{ Definition } & \multicolumn{1}{c}{ Unit } & Symbol \\
\hline Economic Output & Regional GDP output & $\begin{array}{l}10^{8} \text { RMB Yuan } \\
\text { in 1996 price }\end{array}$ & $Y$ \\
\hline Capital Investment & Regional capital investment & $\begin{array}{l}10^{8} \text { RMB Yuan } \\
\text { in } 1996 \text { price }\end{array}$ & $K$ \\
\hline $\begin{array}{l}\text { University education } \\
\text { expenditure }\end{array}$ & $\begin{array}{l}\text { Total regional expenditure on university } \\
\text { education }\end{array}$ & $\begin{array}{l}10^{8} \text { RMB Yuan } \\
\text { in 1996 price }\end{array}$ & $E_{u}$ \\
\hline $\begin{array}{l}\text { Basic education } \\
\text { expenditure }\end{array}$ & $\begin{array}{l}\text { Total regional expenditure on basic } \\
\text { education }\end{array}$ & $\begin{array}{l}10^{8} \text { RMB Yuan } \\
\text { in 1996 price }\end{array}$ & $E_{b}$ \\
\hline $\begin{array}{l}\text { Labors with university } \\
\text { education }\end{array}$ & $\begin{array}{l}\text { Population of employment who have } \\
\text { received university education }\end{array}$ & $\begin{array}{l}10 \text { thousands } \\
\text { of people }\end{array}$ & $L_{u}$ \\
\hline $\begin{array}{l}\text { Labors with basic } \\
\text { education }\end{array}$ & $\begin{array}{l}\text { Population of employment who have } \\
\text { received basic education }\end{array}$ & $\begin{array}{l}10 \text { thousands } \\
\text { of people }\end{array}$ & $L_{b}$ \\
\hline Labor & Population of employment & $\begin{array}{l}10 \text { thousands } \\
\text { of people }\end{array}$ & $L$ \\
\hline Average schooling years & The average schooling year of the total & Years & $S$ \\
\hline population & Total regional expenditure on education & $\begin{array}{l}10^{8} \text { RMB Yuan } \\
\text { in 1996 price }\end{array}$ & $E$ \\
\hline
\end{tabular}

Furthermore, the binary contiguity matrix is used in the study. It is assumed that one province is adjacent to several provinces. The impacts of education of surrounding provinces affect the economic growth of the province per se. This spatial weighted matrix $W$ is modeled in the following way. If two regions are spatially adjacent, its value is 1 . Otherwise the value is 0. Each row of the spatial weighted matrix is normalized (LeSage, Pace 2009). This matrix is the most widely used one in spatial panel model. This matrix is found in Ghosh (2010) and related literature.

\section{Empirical analysis and results}

In this section, spatial autocorrelations of education variables are estimated in global level and local level. Furthermore, the spatial autoregressive model and spatial error model are adopted to estimate the impacts of educational factors on economic growth.

\subsection{The spatial autocorrelation test of provincial education expenditure growth and average schooling years}

The impacts of educational factor on economic growth and the spatial distribution across Chinese provinces are the main questions investigated in this paper. The disparities in spatial distribution of educational factors can be treated as the main driver of the spillover effect. Thus, the spatial distribution of educational factors is investigated first. 


\subsection{Global spatial test of provincial educational factors}

To explore the spatial distribution of educational factors, we firstly conduct a Moran's Index test, which is a widely accepted approach of spatial autocorrelation analysis proposed by Moran (1950). Table 2 shows that the global Moran's Index of average schooling years is positive during 1996 and 2010 at $1 \%$ level of significance, while the index of education expenditure growth indicates mixed effects (not significant during 2001 and 2005, significant at $10 \%$ level of significance in other periods). Thus, it can be concluded that education expenditure growth and average schooling years have significant spatial autocorrelation, and the positive spatial autocorrelation is most remarkable.

Table 2. Global Moran's Index of education expenditure growth and average schooling year in China during 1996 and 2010

\begin{tabular}{ccccccc}
\hline & \multicolumn{3}{c}{ Education Expenditure Growth } & \multicolumn{3}{c}{ Average Schooling Year } \\
\cline { 2 - 7 } & $1996-2000$ & $2001-2005$ & $2006-2010$ & $1996-2000$ & $2001-2005$ & $2006-2010$ \\
\hline $\begin{array}{c}\text { Moran's } \\
\text { Index }\end{array}$ & $0.1877^{*}$ & 0.1000 & $0.2012^{\star}$ & $0.3442^{* * *}$ & $0.3536^{* * *}$ & $0.3466^{* * *}$ \\
\hline$Z(I)$ & 1.6564 & 1.0122 & 1.7697 & 2.9724 & 3.0718 & 2.9865 \\
\hline$P$-value & 0.0976 & 0.3115 & 0.0768 & 0.003 & 0.0021 & 0.0028 \\
\hline
\end{tabular}

Note: ${ }^{*},{ }^{*}$ and ${ }^{* * *}$ indicate rejection of the null hypothesis at $1 \%, 5 \%$ and $10 \%$ level of significance, respectively.

\subsection{Local spatial test of provincial educational factors}

In this paper, we try to examine the spatial distribution of educational factors in Mainland China. The local spatial autocorrelation estimation can further pinpoint the spatial relations among different provinces. Figures 2-5 shows local Moran's I index of provincial average schooling years and education expenditure growth (The local Moran's I index of provincial average schooling years is displayed in just one figure, as its clustering types are the same during the three five-year plans.)

Combining Moran's scatter plot with local Moran's index, the clustering LISA maps are depicted in Figures 2-5, which demonstrates the clustering types of provincial average schooling years. These clustering types can indicate the agglomeration structure of educational resources taking into account the spatial relations between neighboring provinces. Take $\mathrm{LH}$ and $\mathrm{HH}$ clustering as examples. $\mathrm{LH}$ clustering is a region of lower variable value surrounded by regions of higher variable values. HH clustering is a region of higher variable value surrounded by regions of higher variable values.

It can be seen that China's average schooling years has a similar spatial structure during the three five-year plans in Figure 2. Four provinces in the west fall into the category of LL clustering type (Qinghai, Tibet, Sichuan and Yunnan). Xinjiang falls into HL clustering type. Hebei and Tianjin in the north fall into $\mathrm{HH}$ clustering type. This indicates that there is a distinct spatial agglomeration region with higher average schooling years in $\mathrm{He}$ bei province itself and its neighboring provinces. It also indicates that the four provinces in the west show a trend of spatial agglomeration with lower average schooling years. 


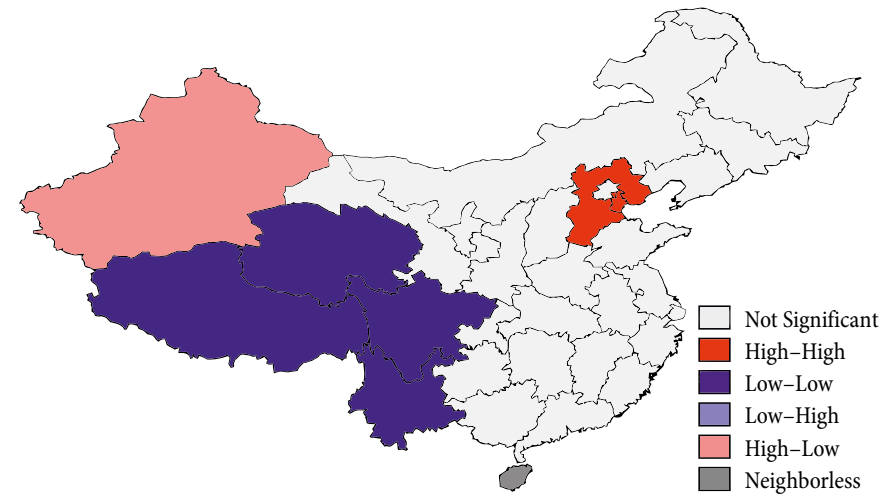

Fig. 2. The Local Moran's Index of provincial average schooling year during 1996 and 2010

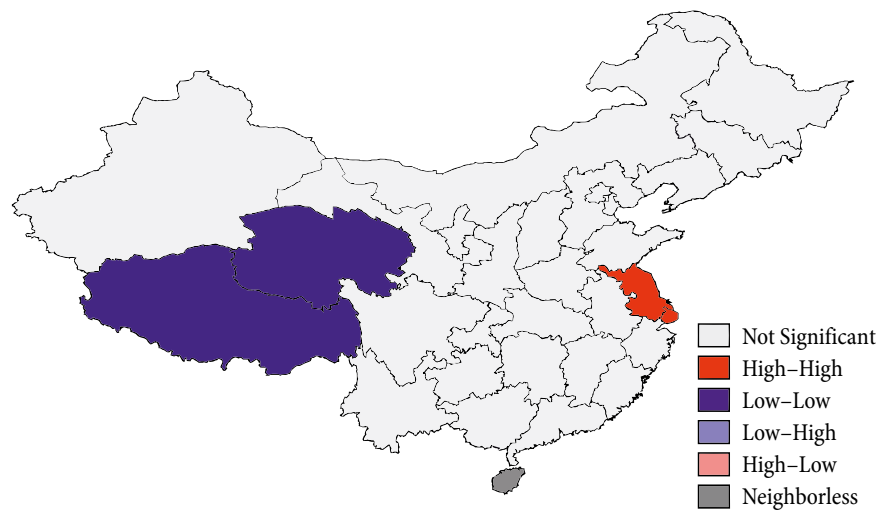

Fig. 3. The Local Moran's Index of provincial education expenditure growth during 1996 and 2000

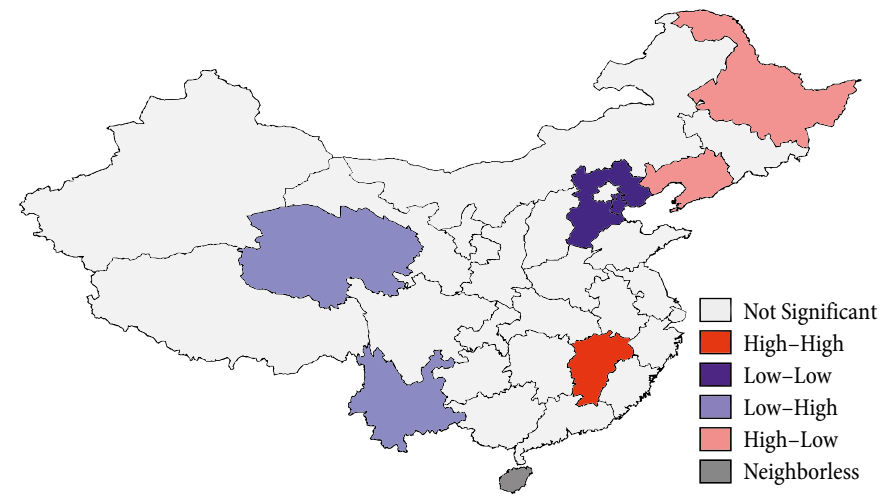

Fig. 4. The Local Moran's Index of provincial education expenditure growth during 2001 and 2005 


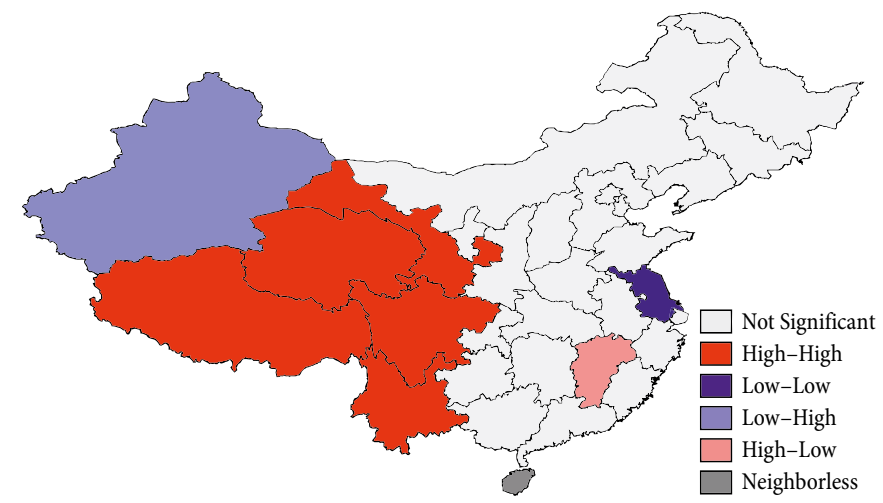

Fig. 5. The Local Moran's Index of provincial education expenditure growth during 2006 and 2010

The HL clustering type, Xinjiang, has the highest value among neighboring provinces. In addition, the values of other provinces are not significant in local Moran's I index, which indicates that there is no significant spatial autocorrelation with other regions in China.

Furthermore, Figures 3-5 show the spatial distribution of clustering types of education expenditure growth. Provinces in the west are gradually changing from LL to HH clustering type, while Jiangsu is gradually changing from HH to LL. Jiangxi is changing from insignificant clustering type to HL clustering type. During 2000 and 2005, Heilongjiang and Liaoning fall into HL, while Hebei and Tianjin are in LL. The figures indicate that national education expenditure growth is continuously increasing during 1996 and 2010, while these of provinces in the east show a mixed spatial structure. Education expenditure growth of provinces in the northeast shows a more positive structure than Hebei and Tianjin. In addition, Jiangxi has the highest education expenditure growth. It implies that the education expenditure growth in coastal provinces in southeast China has spillover effects. The effects spread from central provinces to western provinces, especially to adjacent provinces.

It can be concluded that most provinces in the west have lower quality of human capital (average schooling years) but increasing education expenditure growth. Moreover, the agglomeration of higher average schooling years is located in Bohai Rim region. Thirdly, provinces in the east display a decreasing trend of education expenditure growth and positive spillover effects.

\subsection{Empirical results}

To establish spatial regression estimation, global Moran's I test is conducted to estimate the spatial correlation of regional economies. The results indicate that GDP and GDP growth have spatial autocorrelation in Global Moran's index (pass 5\% and 10\% significance test). Therefore, a spatial model is suitable for this study. For the panel data set that covers 31 provinces and spans over 15 years, Hausman test is performed to choose between fixed effect test and random effect test. The results are in favor of fixed effect model (both $p$ values are 0 ). Thus, the spatial panel estimation model with fixed effect is adopted. The range of 
the Variance Inflation Factor (VIF) of the independent variables is $[2.4680,4.5100]$ in the model of average schooling years and [1.0570, 4.8060] in the model of education expenditure growth. Note that there is no multicollinearity among independent variables. In addition, Lagrange Multiplier (LM) tests indicate that SAR and SEM models with spatial fixed effects are suitable for regional panel data (1\% level of significance) (Anselin 1996). The results indicate that the LM-lag result of average schooling years is 311.98 ( $\mathrm{p}$ value is 0.0000 ), and the result of LM-err is 121.05 ( $\mathrm{p}$ value is 0.0000 ). The LM-lag result of education expenditure growth is 179.50 ( $\mathrm{p}$ value is 0.0000 ), and the result of LM-err is 204.25 ( $\mathrm{p}$ value is 0.0000 ). The results indicate that both spatial autoregressive effect and spatial error effect exist. Table 3 shows the results of SAR, and Table 4 shows the results of SEM.

Table 3 reveals that dual-sector SAR and SEM models are more accurate estimation methods than the classical model (adjusted R-square values of SAR and SEM models are higher than that of classical model). $\theta$, spillover effect of expenditure from education sector to non-education sectors, is significant in SEM model. It means that a $1 \%$ increase of expenditure in education sector is estimated to increase expenditure in non-education sec-

Table 3. Spatial econometric estimations of dual-sector feder model

\begin{tabular}{|c|c|c|c|c|c|c|}
\hline & Fixed-Effect & $t$-statistics & SAR & $t$-statistics & SEM & $t$-statistics \\
\hline$K / Y$ & $0.1023^{* * *}$ & $(16.9165)$ & $0.0646^{\star * *}$ & $(9.8231)$ & $0.1069^{\star * *}$ & $(14.0820)$ \\
\hline$L$ & $0.2054^{\star \star \star *}$ & $(6.9045)$ & $0.1301^{\star * *}$ & $(5.0374)$ & $0.1193^{\star * *}$ & $(4.7550)$ \\
\hline$\delta /(1+\delta)-\theta$ & -0.2931 & $(-0.7115)$ & $-0.7401^{\star *}$ & $(-2.1019)$ & $-1.4007^{\star * *}$ & $(-4.1711)$ \\
\hline$\theta$ & $-0.0462^{* *}$ & $(-2.1672)$ & 0.00002 & $(0.0010)$ & $0.0424^{* *}$ & $(2.2038)$ \\
\hline$\delta$ & -0.2533 & & -0.4253 & & -0.5759 & \\
\hline Adj- $R^{2}$ & 0.4512 & & 0.7256 & & 0.5683 & \\
\hline$\rho$ & & & $0.4740^{\star * *}$ & $(11.4604)$ & & \\
\hline$\lambda$ & & & & & $0.6490^{* * *}$ & $(16.5073)$ \\
\hline
\end{tabular}

Note: ${ }^{*},{ }^{*}$ and ${ }^{* *}$ indicate rejection of the null hypothesis at $1 \%, 5 \%$ and $10 \%$ level of significance, respectively.

Table 4. Full sample estimation of educational impacts in spatial panel models

\begin{tabular}{|c|c|c|c|c|c|c|}
\hline & Fixed-Effect & $t$-statistics & SAR & $t$-statistics & SEM & $t$-statistics \\
\hline$K$ & $0.0125^{\star *}$ & $(-2.0984)$ & $0.0080^{* * *}$ & $(2.985)$ & $0.0068^{* * *}$ & $(2.8098)$ \\
\hline$\overline{E_{u}}$ & -0.0009 & $(-0.1472)$ & 0.0038 & $(1.4451)$ & $0.0059^{* *}$ & $(2.4166)$ \\
\hline$E_{b}$ & $0.7192^{\star * *}$ & $(32.5363)$ & $0.1061^{* * *}$ & $(6.8586)$ & 0.0224 & $(1.1414)$ \\
\hline$L_{u}$ & -0.0008 & $(-0.1349)$ & 0.0022 & $(0.8023)$ & 0.0006 & $(0.2346)$ \\
\hline$L_{b}$ & 0.0489 & $(0.8882)$ & 0.0389 & $(1.5617)$ & $0.0507^{\star *}$ & $(2.2373)$ \\
\hline$S$ & $0.5477^{\star * \star}$ & $(3.1864)$ & $0.1862^{* *}$ & $(2.2945)$ & $0.2809^{* * *}$ & $(3.1241)$ \\
\hline Adj-R ${ }^{2}$ & 0.9873 & & 0.9976 & & 0.8586 & \\
\hline$\rho$ & & & $0.7994^{* * *}$ & $(39.4654)$ & & \\
\hline$\lambda$ & & & & & $0.9541^{\star * *}$ & $(121.7134)$ \\
\hline
\end{tabular}

Note: ${ }^{*},{ }^{*}$ and ${ }^{* * *}$ indicate rejection of the null hypothesis at $1 \%, 5 \%$ and $10 \%$ level of significance, respectively. 
tors by approximately $0.0424 \%$ considering spatial effect of economic shock. Thus, spillover effect from education sector to non-education sectors can be regarded as a positive impact on economic growth. In addition, both $\rho$ in SAR and $\lambda$ in SEM are positive and significant at the $1 \%$ level, which means that there is significant positive spatial correlation between economic growth and its shocks among the 31 provinces. It is worth noting that $\delta$ can be deduced from equation (14), SAR and SEM models. $\delta$ s are all negative, which indicates that the impact of education sector on economic growth is still lower than that of noneducation sectors. Compared with Cai (1999), the dual-sector difference of impacts on economic growth is greater, and education expenditure growth has a weaker influence on economic growth with economic spatial spillover. In addition, both studies demonstrate that education expenditure growth has significantly increased regional economic growth.

As shown in Table 4, the SAR model provides more accurate results than classical regression, and SEM also has a high adjusted R-square value (0.8586). Both SAR and SEM estimations show similar impacts of average schooling years on economic output (real GDP), which are about 0.1862 and 0.2809 and significant at the $1 \%$ level. This means that a $1 \%$ increase of average schooling years is estimated to increase economic output by $0.1862 \%$ in SAR model and $0.2809 \%$ in SEM model. And a $1 \%$ increase of capital investment is associated with a $0.0080 \%$ increase of GDP in SAR model and a $0.0068 \%$ increase of GDP in SEM model. The coefficients of average schooling years are higher than that of labor force and capital investment in both models, which indicates that educated labor force could improve the regional economic growth. Furthermore, both $\rho$ in SAR and $\lambda$ in SEM are positive and significant at the $1 \%$ level, which means that there are significantly positive spatial spillovers of economic output and economic shocks among the 31 provinces.

Compared with Lin (2003) and Cai (1999), the impacts of educational factors are quite similar. Nevertheless, the effect estimation of the average schooling years in this paper is slightly higher than previous results due to the spatial spillover effect. Furthermore, expenditures on university education and basic education show different results in SAR and SEM models. A $1 \%$ increase of university expenditure and labor force with basic education is associated with $0.0059 \%$ and $0.0507 \%$ increase of GDP in SEM model and a $1 \%$ increase of expenditure on basic education is associated with a $0.1061 \%$ increase of GDP in SAR model. It can be inferred that expenditure on basic education has significant positive impact on regional economic growth considering spillover of economic outputs. Expenditures on university education and the number of people with basic education affected by spillover of economic shock, may also affect potential regional economic growth positively.

\subsection{Cumulative effect analysis}

To further explore the impacts of educational factors and their regional disparities, the cumulative effect analysis is conducted. Note that direct effect of educational factors indicates the impact on local economic output. Indirect effect represents the indirect impacts of educational factors on the economic output of other regions through spatial spillover. Cumulative effect can examine the total impacts of the educational factors of particular regions on their own economic output as well as the impacts on other regions. Cumulative 
effect estimations of the whole nation ${ }^{1}$, eastern region, central region and western region are shown in Table 5.

It can be seen in Table 5 that regional disparities in cumulative effect of the educational factors on the economic output are evident. To interpret the results, we take $L_{b}$ as an example. If $L_{b}$ of eastern region increases by $1 \%$, a short and direct increase of $0.0911 \%$ might take place in its local economic output. Moreover, an increase of $0.1172 \%$ might affect eastern neighboring provinces as well. The spillover to neighboring provinces is defined as the indirect impact coefficient. A $1 \%$ increase of $L_{b}$ would cause a $0.2083 \%$ increase in eastern region. It is a more appropriate estimation result with the consideration of the impacts of spillovers. Compared with other three regions, the number of people who have received basic education has a significant positive effect on the economic output in eastern region of China, while it has a significant negative effect on central and western regions of China. It can be interpreted that a large amount of people, especially those people who do not have specific skills or higher education, might move to eastern region for temporary well-paid

Table 5. Regional cumulative effect analysis of educational factors

\begin{tabular}{|c|c|c|c|c|c|}
\hline Indicators & Impact & Nationwide & Eastern & Central & Western \\
\hline \multirow[t]{3}{*}{$\bar{K}$} & Direct & $0.0101^{\star \star \star}$ & $0.1482^{* * *}$ & $0.3288^{\star \star \star}$ & $0.0089^{\star * *}$ \\
\hline & Indirect & $0.0301^{\star \star *}$ & $0.1909^{* * *}$ & $0.1505^{\star * *}$ & $0.0210^{\star * \star}$ \\
\hline & Total & $0.0402^{\star \star *}$ & $0.3390^{* * *}$ & $0.4792^{* * *}$ & $0.0299^{\star * *}$ \\
\hline \multirow[t]{3}{*}{$E_{u}$} & Direct & 0.0046 & $-0.0693^{* *}$ & $0.0518^{*}$ & $0.0070^{* *}$ \\
\hline & Indirect & 0.0137 & $-0.0893^{\star *}$ & $0.0236^{*}$ & $0.0165^{\star \star}$ \\
\hline & Total & 0.0183 & $-0.1586^{\star *}$ & $0.0754^{\star}$ & $0.0235^{\star \star}$ \\
\hline \multirow[t]{3}{*}{$E_{b}$} & Direct & $0.1343^{* * *}$ & $0.2292^{* * *}$ & -0.0311 & $0.1207^{\star * *}$ \\
\hline & Indirect & $0.3939^{\star * *}$ & $0.2932^{* * *}$ & -0.0157 & $0.2817^{\star \star \star}$ \\
\hline & Total & $0.5282^{\star \star \star}$ & $0.5224^{* * *}$ & -0.0468 & $0.4023^{\star \star *}$ \\
\hline \multirow[t]{3}{*}{$L_{u}$} & Direct & 0.0030 & 0.0098 & -0.0606 & 0.0001 \\
\hline & Indirect & 0.0089 & 0.0127 & -0.0274 & 0.0003 \\
\hline & Total & 0.01183 & 0.0225 & -0.0881 & 0.0004 \\
\hline \multirow[t]{3}{*}{$L_{b}$} & Direct & 0.0479 & $0.0911^{*}$ & $-0.3912^{\star}$ & $-0.4472^{\star * *}$ \\
\hline & Indirect & 0.1422 & $0.1172^{\star}$ & $-0.1773^{*}$ & $-1.0516^{\star * *}$ \\
\hline & Total & 0.1901 & $0.2083^{\star}$ & $-0.5685^{\star}$ & $-1.4988^{\star \star *}$ \\
\hline \multirow[t]{3}{*}{$S$} & Direct & $0.2372^{\star \star}$ & $0.7154^{* * *}$ & $0.8581^{\star *}$ & $0.7657^{\star \star * *}$ \\
\hline & Indirect & $0.6953^{\star *}$ & $0.9177^{\star * *}$ & $0.3889^{\star *}$ & $1.7967^{\star \star \star}$ \\
\hline & Total & $0.9325^{\star *}$ & $1.6331^{\star * *}$ & $1.2470^{\star \star}$ & $2.5623^{\star * *}$ \\
\hline
\end{tabular}

Note: ${ }^{*},{ }^{*}$ and ${ }^{* *}$ indicate rejection of the null hypothesis at $1 \%, 5 \%$ and $10 \%$ significant level, respectively.

\footnotetext{
${ }^{1} 31$ provinces in mainland China are Beijing, Tianjin, Hebei, Liaoning, Shanghai, Jiangsu, Zhejiang, Fujian, Shandong, Guangdong, Hainan (these 11 provinces are classified as eastern region), Shanxi, Inner Mongolia, Jilin, Heilongjiang, Anhui, Jiangxi, Henan, Hubei, Hunan, Guangxi (these 10 provinces are classified as central region), Sichuan, Chongqing, Guizhou, Yunan, Tibet, Shaanxi, Gansu, Qinghai, Ningxia, Xinjiang (these 10 provinces are classified as western region).
} 
jobs (eastern region is the most developed region in China, producing more than half of China's economic output). The migrant labor force benefits the economic growth of eastern region, but reduces the labor force of other regions. Thus, significant negative coefficients are found for central region and western region.

Table 5 reveals that all the coefficients of capital investment and average schooling years are significantly positive, which shows significant spillover effect across all provinces in China. Expenditure on basic education is not significant in central region but significant in the whole nation. This reveals that potential cross-region spillover exists between eastern region and western region. Furthermore, labor force with basic education has a more significant impact on economic growth than labor force with university education. The impact of expenditure on basic education is also more significant than that of expenditure on university education. It can be inferred that basic education might play a more important role in improving national economic growth than university education in China during 1996 and 2010. It can be explained by two justifications. (1) The average schooling years of China in 2010 is almost 8 years. It means that a certain amount of labor force could not receive university education. Thus, basic education plays a more important role in developing economy by affecting labor force of low education level. (2) Better basic education can also improve the quality of university education. It can indirectly increase the economic output.

\section{Policy implications}

(1) Education developments should be encouraged to increase regional economic output due to two reasons. The first is that the positive impacts (direct and indirect impacts) of average schooling years are higher than that of labor force and capital investment, enhancing the level of public education proves to be a key factor in economic growth. Recent economic development in China, along with the empirical findings, provides evidence for the argument of Hanushek and Kimko (2000), Hanushek and Woessmann (2008). The second refers to the fact that education sector benefits non-education sectors on economic output through positive spillovers from education sector to non-education sectors. Based on aforementioned findings, three policies are proposed to improve the impacts of education on economic growth. Firstly, government should provide more funding to maintain sustainable growth of public education in China, e.g., education expenditure and teacher training projects. Besides, for the significant positive effects (direct and indirect impacts) of expenditure and labor force with basic education, more expenditure should be provided to develop basic education. Secondly, waste of education resource should be minimized, e.g., canceling redundant educational projects, adjusting inefficient management and allocation of public education expenditure etc. Thirdly, as Chinese education expenditure is mainly funded by the government (ratio of private education expenditure to public one is just $0.5620 \%$ in 2010), the scope of education expenditure sources should be further expanded. It implies that more private investment might be channeled to participate in competition of the education market to enhance education quality.

(2) Due to the obvious regional disparities of the level of public education in China, government should set more supportive policies for less-developed regions so as to reduce 
disparities between eastern-western regions and rural-urban regions, e.g., extra government expenditure is required, and schooling quality should be improved in less-developed regions. Moreover, balanced distribution of educated labor force is also required to narrow the gaps among different regional economic growth. For example, given the negative impacts of people with basic education in central region and western region, the government should create more incentives to attract more labor force with basic education, especially the local labor force, for its economic development. In eastern region, more expenditure on university education does not seem to be efficient (negative coefficient in regression). Thus, the main focus of education in eastern region should be improvement on the quality of education, e.g., more academic competitions and awards, educational information technology and international educational cooperation should be provided to university education, making full use of the developed economy in eastern region.

(3) Empirical results show significant spatial autocorrelations in education expenditure and in average schooling years across regions of China. Furthermore, the results indicate that both basic education expenditure and average schooling years have positive spillover effects on economic growth nationwide. We can conclude that the impacts of education on economic growth might be underestimated in existing research. Thus the spatial impacts of neighboring regions should not be neglected while making education policies. Given the potential spillover effect of the difference between expenditure on basic education in eastern region and west region, more policies on regional integration and establishing spillover channels of human capital and education expenditure should be encouraged, such as regional collaborations of schools, cross-regional education projects and contests for students and teachers.

\section{Conclusions}

This paper uses spatial panel model and Feder dual-sector model to estimate the direct and indirect educational impacts (spillover effect) on economic growth across 31 provinces in China during 1996 and 2010. The economic impacts of educational factors are divided into education sector and non-education sectors, basic education and university education.

Judging from the estimation results of the period 1996-2010, education developments play a central role in economic growth. This paper provides empirical evidences to the following arguments. (1) Education expenditure and average schooling years are important factors in economic development. Both factors have spillover effects on neighboring regions. Compared with the expenditure on university education, expenditure on basic education plays a more positive role in economic growth in China. (2) Impact of education sector on economic growth is still lower than that of non-education sectors. There are positive spillovers from education sector to non-education sectors taking into account spatial effects of economic growth shock. (3) Impacts of average schooling years and education expenditure in spatial panel models are lower than that of previous results (Lin 2003; Cai 1999). It means that economic growth is partially caused by the educational and relative economic spillover effects of neighboring regions. Aforementioned findings may provide some suggestions to other developing countries, where the public education sector plays 
an important role in the national economy. These findings can be further utilized by policy makers to analyze the relation between education and economic growth with spatial spillover effect and dual-sector spillover effect.

Note that the spatial spillover effect in this paper is estimated among all Chinese regions. It indicates that the significant spatial impacts of neighboring regions cannot be neglected. This paper can be further extended to analyze the local spillover effect from one specific region to another region. Regarding this issue, we can further examine regional disparity of spillover effect of different educational factors, which may provide more insights into improving the regional education level and the regional allocation of educational investment and educated labor force. These issues may provide more useful guidance on policymaking in developing countries.

\section{Acknowledgements}

This research was supported by grant of Humanities and Social Sciences of Chinese Ministry of Education (No.10YJc880039).

\section{References}

Anselin, L. 1996. Spatial analytical perspectives on GIS. CRC Press. $111 \mathrm{p}$.

Arayama, Y.; Miyoshi, K. 2004. Regional diversity and sources of economic growth in China, World Economic growth 27(10): 1583-1607. http://dx.doi.org/10.1111/j.1467-9701.2004.00668.x

Barro, R. 1991. Economic growth in a cross-section of countries, Quarterly Journal of Economics 106(2): 407-443.

Beijing Statistics Bureau, Survey Office of the National Bureau of Statistics in Beijing. 1996-2011. Beijing statistical yearbook. China Statistics Press.

Blair, J. P.; Staley, S. 1995. Quality competition and public schools: further evidence, Economics of Education Review 14(2): 193-198. http://dx.doi.org/10.1016/0272-7757(95)90398-R

Brehm, S. 2013. Fiscal Incentives public spending, and productivity - county-level evidence from a Chinese province, World Development 46: 92-103. http://dx.doi.org/10.1016/j.worlddev.2013.01.029

Cai, Z. 1999. Econometric analysis of the contribution of education to economic growth, Journal of Economic Research 2: 67-79 (in Chinese).

Castelló, A.; Doménech, R. 2002. Human capital inequality and economic growth: some new evidence, The Economic Journal 112(478): 187-200. http://dx.doi.org/10.1111/1468-0297.00024

Castelló-Climent, A.; Hidalgo-Cabrillana, A. 2012. The role of educational quality and quantity in the process of economic development, Economics of Education Review 31: 391-409. http://dx.doi.org/10.1016/j.econedurev.2011.11.004

Chen, J.; Fleisher, B. M. 1996. Regional income inequality and economic growth in China, Journal of Comparative Economics 22(15): 141-164. http://dx.doi.org/10.1006/jcec.1996.0015

Department of Population and Employment Statistics, National Bureau of Statistics, Department of Planning and Finance, Ministry of Human Resources and Social Security. 1996-2011. China labor statistics yearbook. China Statistics Press.

Department of Population, Social Science and Technology Statistics National Bureau of Statistics of China. 1996-2011. China population statistics yearbook. China Statistics Press. 
Division of Developing and Planning, Ministry of Education of the People's Republic of China. 19962011. China Education statistics yearbook. People's Education Press.

Easterly, W.; Levine, R. 1997. Africa's growth tragedy: policies and ethnic divisions, Quarterly Journal of Economics 112(4): 1203-1250. http://dx.doi.org/10.1162/003355300555466

Elhorst, J. P. 2003. Specification and estimation of spatial panel data models, International Regional Science Review 26(3): 244-268. http://dx.doi.org/10.1177/0160017603253791

Frini, O.; Muller, C. 2012. Demographic transition, education and economic growth in Tunisia, Economic Systems 36: 351-371. http://dx.doi.org/10.1016/j.ecosys.2012.04.002

Ganegodage, K. R.; Rambaldi, A. N. 2011. The impact of education investment on Sri Lankan economic growth, Economics of Education Review 30: 1491-1502.

http://dx.doi.org/10.1016/j.econedurev.2011.08.001

Ghosh, S. 2010. Strategic interaction among public school districts: evidence on spatial interdependence in school inputs, Economics of Education Review 29: 440-450.

http://dx.doi.org/10.1016/j.econedurev.2009.10.001

Grundey, D.; Sarvutyte, M. 2007. The implications of financing higher education in the context of labour force migration: the case of Lithuania, Technological and Economic Development of Economy 13(3): 208-213.

Hanushek, E.; Kimko, D. 2000. Schooling, labor force quality and the growth of nations, American Economic Review 90(5): 1184-1208. http://dx.doi.org/10.1257/aer.90.5.1184

Hanushek, E.; Woessmann, L. 2008. The role of cognitive skills in economic development, Journal of Economic Literature 46(3): 607-668. http://dx.doi.org/10.1257/jel.46.3.607

Heilongjiang Provincial Statistics Bureau. 1996-2011. Heilongjiang statistical yearbook. China Statistics Press.

Jalil, A.; Idrees, M. 2013. Modeling the impact of education on the economic growth: evidence from aggregated and disaggregated time series data of Pakistan, Economic Modelling 31: 383-388. http://dx.doi.org/10.1016/j.econmod.2012.11.035

Jiangsu Provincial Statistics Bureau. 1996-2011. Jiangsu statistical yearbook. China Statistics Press.

Krueger, A.; Lindahl, M. 2001. Education for growth: why and for whom?, Journal of Economic Literature 39(4): 1101-1136. http://dx.doi.org/10.1257/jel.39.4.1101

Lee, L.; Yu, J. 2010. Estimation of spatial autoregressive panel data models with fixed effects, Journal of Econometrics 154: 165-185. http://dx.doi.org/10.1016/j.jeconom.2009.08.001

Lee, S.; Malin, B. A. 2013. Education's role in China's structural transformation, Journal of Development Economics 101: 148-166. http://dx.doi.org/10.1016/j.jdeveco.2012.10.006

LeSage, J. P.; Pace, R. K. 2009. Introduction of Spatial Econometrics. Boca Raton: CRC Press. 8 p. http://dx.doi.org/10.1201/9781420064254

Lin, T. 2003. Education, technical progress, and economic growth: the case of Taiwan, Economics of Education Review 22(2): 213-220. http://dx.doi.org/10.1016/S0272-7757(02)00030-4

Li, S.; Whalley, J.; Xing, C. 2014. China's higher education expansion and unemployment of college graduates, China Economic Review 30: 567-582. http://dx.doi.org/10.1016/j.chieco.2013.08.002

Lucas, R. E. 1988. On the mechanics of economic development, Journal of Monetary Economics 22: 3-42. http://dx.doi.org/10.1016/0304-3932(88)90168-7

Moran, P. A. P. 1950. A test for the serial dependence of residuals, Biometrika 37: 178-181. http://dx.doi.org/10.1093/biomet/37.1-2.178

National Bureau of Statistics of China. 1996-2011. China statistics yearbook. China Statistics Press.

Pan, L. 2014. The impacts of education investment on skilled-unskilled wage inequality and economic development in developing countries, Economic Modelling 39: 174-181.

http://dx.doi.org/10.1016/j.econmod.2014.02.040 
Romer, P. E. 1990. Endogenous technological changes, Journal of Political Economic Growth 98(5): 71-102. http://dx.doi.org/10.1086/261725

Sala-I-Martin, X.; Doppelhofer, G.; Miller, R. 2004. Determinants of long-term growth: a Bayesian averaging of classical estimates (BACE) approach, American Economic Review 94(4): 813-835. http://dx.doi.org/10.1257/0002828042002570

Shanghai Municipal Statistics Bureau, Survey Office of the National Bureau of Statistics in Shanghai. 1996-2011. Shanghai statistical yearbook. China Statistics Press.

Shindo, Y. 2010. The effect of education subsidies on regional economic growth and disparities in China, Economic Modelling 27: 1061-1068. http://dx.doi.org/10.1016/j.econmod.2010.04.003

Sylwester, K. 2000. Income inequality, education expenditure and growth, Journal of Development Economics 63(2): 43-52. http://dx.doi.org/10.1016/S0304-3878(00)00113-9

Wei, Y.; Liu, X.; Song, H.; Romily, P. 2001. Endogenous innovation growth theory and regional income convergence in China, Journal of International Development 13: 153-168. http://dx.doi.org/10.1002/jid.721

Zhang, H. 2014. The poverty trap of education: education-poverty connections in Western China, International Journal of Educational Development 38: 47-58. http://dx.doi.org/10.1016/j.ijedudev.2014.05.003

Zhejiang Provincial Statistics Bureau, 1996-2011. Zhejiang statistical yearbook. China Statistics Press.

Kangjuan LV. PhD, professor, associate Dean of SILC Business School, Shanghai University. Visiting scholar of Cambridge University, UK. Research direction is urban economic management, spatial economy.

Anyu YU. Master Candidate, Shanghai University. Research direction is spatial econometrics.

Siyi GONG. PhD, professor, Shanghai University. Visiting professor of University of Technology, Sydney. Research direction is educational economic management.

Maoguo WU. PhD, lecture, Shanghai University. Research direction is regional economics.

Xiaohong XU. PhD Candidate, Senior lecturer, Shanghai University. Research direction is educational research. 